\title{
The role of the different concentrations of GA3 on Seed Germination and Seedling Growth of Loquat (Eriobotrya japonica L.)
}

\author{
Dr. Shabaq Muhamad Nafea Al-Hawezy \\ Forestry and Horticulture Dept., College of Agriculture/ University of Salahaddin, Erbil/Iraq
}

\begin{abstract}
Seed germination of loquat (Eriobotrya japonica L.) using concentration and soaking duration of Gibberellin acid (GA3) treatments was studied at the lathhouse of Agriculture Research Centre / Ainkawa / Erbil for the period from $15^{\text {th }}$ May to $14^{\text {th }}$ September 2010. Seed treated with GA3 (150, 200 and 250) $\mathrm{mg} \cdot \mathrm{L}^{-1}$ in addition to comparison treatment (zero mg. $\mathrm{L}^{-1}$ ) at three different soaking time (12, 24 and 36) hour to production strong seedling within a short period. The study relied on Complete Randomized Design (C.R.D) as a factorial experiment, 20 seeds were used in each treatment, each trial replicated three times that mean 36 trials. Average results were obtained in each trial based on less difference and $5 \%$ approximate ratio was given (least significant differences). According to the results found in this study, the quick and uniform, germination of loquat seeds and growth of seedlings indicate high vigor of seeds.

GA3 had a significant effect on germination rate as compared to control. GA3 at 250mg. $L^{-1}$ gave best response $(71.19,86.80$ and 98.75$) \%$ at $1^{\text {st }}, 2^{\text {nd }}$ and $3^{\text {rd }}$ weeks, but as the concentration increased above 250 $m g . L^{-1}$ the germination rate decreased rapidly but shoots and root length of seedling and vigor index increased during300 mg. $L^{-1}$. Soaking period did not affect significantly on loquat seed germination ratio at $1^{\text {st }}$ and $3^{\text {rd }}$ weeks while in $2^{\text {nd }}$ Week after germination the ratio increased significantly with increasing soaking period.

Different effects of combined GA3 concentration and soaking period on the loquat seed germination rate and seedling growth parameters. More significant effect interactions were obtained in $250 \mathrm{mg} \cdot \mathrm{L}^{-1}$ GA3 with different period times.
\end{abstract}

Key words: GA3, loquat, period, Seed, soaking

\section{Introduction}

Loquat is an important fruit crop; it gives good returns to the growers, as there is no other fresh fruit available in the market during March / April. Loquats are mainly propagated through seed, so it has led to development of many new accessions, which are result of different crosses occurring in the orchards naturally. The seed is the structure consisting of a cover, an embryo and some supplemental foods, which enables the embryo to survive the period of time between seed maturation and seedling establishment thereby ensuring the initiation of the next generation. Dormancy is a condition in which seeds do not germinate even when the environmental conditions (i.e., water, temperature and light) are suitable for germination. Seeds are of importance for propagating seedling rootstocks on which to graft or bud varieties, and for obtaining hybrid plants in breeding studies (Westwood, 1995; Hartmann et al., 1997). Exogenous growth regulator treatments gibberellins (usually gibberellic acid GA3 have been shown to break dormancy in many seed species (Dweikat and Lyrene, 1988; Karam and Al-Salem, 2001; Mehanna et al., 1985).

Endogenous dormancy of loquat seeds reduces loquat industry development (El-Dengawy, 2005). Loquat use as a rootstock for quince, however, the quince rootstock is usually used in spite of its undesirable characteristics such as shallow root system and the high susceptibility to salinity stress. Loquat seed germination is important in propagation and breeding programs. Breaking seed dormancy is necessary for the completion of germination. Various dormancy breaking and germination stimulating treatments have been tried with seeds of many fruit species such as papaya (Nagao and Furutani, 1986), persimmon (Taha, 1987), peach (El-Khoreiby and Salem, 1985; El-Dengawy, 1997), and loquat (Polat and Kaska, 1992; Polat, 1997), Citrus( Dzayi, 2010). The main aim of this study was for increasing seed germination and subsequent growth of loquat plants using different concentrations and soaking periods of gibberellic acid (GA3), which is naturally occurring plant growth regulator. Presoaking seeds in GA3 cause rapid germination of many highly dormant seeds and are widely used in fruit production.

\section{Material and Methods}

Seed germination of loquat (Eriobotrya japonica L.) using concentration and soaking duration of Gibberellin acid treatments was studied at the lathhouse of Agriculture Research Centre / Ainkawa / Erbil for the period from $15^{\text {th }}$ May to $14^{\text {th }}$ September 2010. Seed treated with GA3 (200, 250 and 300) mg. $\mathrm{L}^{-1}$ in 
addition to comparison treatment (zero mg. $\mathrm{l}^{-1)}$ at three different socking time (12, 24 and 36) hour to production strong seedling within a short period. The percentages of germination of seeds were calculated according to the rules for seed testing (ISTA, 1996). Germination characteristics were recorded daily. The seedlings were allowed to grow for four months (May to September 2010). After four months, five representative seedlings from each replication of a treatment (10 seedlings for each treatment) were selected for measuring growth parameters; shoot and root length, seedling diameter and number of leaf. For recording dry weight, shoots and roots were oven dried at $70 \mathrm{oC}$ for 72 hours.

Vigor index was calculated according to Abdul-baki and Anderson (1973) as germination per cent $\times$ seedling total length (total shoot + root length).

\section{Results And Discussion}

\section{1- Effect of GA3 on Seed Germination and Seedling Growth of Loquat}

The germination percentage results for the loquat seeds treated of the GA3 and control are summarized in Table (1), the percentage differences between treatments and control are significance during germination at $1^{\text {st }}, 2^{\text {nd }}$ and $3^{\text {rd }}$ week. Results showed that treatments of $\left(200,250\right.$ and 300) mg.L ${ }^{-1}$ GA3 have markedly improved germination percentage from $94.56 \%$ to $98.75 \%$, and $94.00 \%$ comparing with control $92.65 \%$ at 3 rd week. The highest germination percent was noted in GA3 $250 \mathrm{mg}^{-1} \mathrm{~L}^{-1}(71.19,86.80$ and 98.75$) \%$ at $1^{\text {st }}, 2^{\text {nd }}$ and $3^{\text {rd }}$ weeks. In Table (1) results are shown the effects of the positive GA3 treatment on shoot and root length of young seedling and vigor index after germinated, The treatment $250 \mathrm{mg} . \mathrm{L}^{-1} \mathrm{GA} 3$ gave the highest values ranging from $8.21 \mathrm{~cm}, 10.15 \mathrm{~cm}$ and 1726.425 comparing with the control $4.86 \mathrm{~cm}, 6.69 \mathrm{~cm}$ and 1070.373 respectively. Loquat seeds treated with $\left(200,250\right.$ and 300) $\mathrm{mg}^{-\mathrm{L}^{-1}} \mathrm{GA} 3$ germinated and grown quickly especially the difference of seedling diameter, number of leaf, vegetative dry weight and root dry weight. The heights significant increase was obtained in the treatment $250 \mathrm{mg} . \mathrm{L}^{-1} \mathrm{GA} 31.69 \mathrm{~mm}, 8.34,0.23 \mathrm{gm}$ and $0.044 \mathrm{gm}$ comparing with control. The present results are in agreement with the findings of Dzayi (2010). The GA3 hormone increases cell size by stimulating the cell wall to release and transmit its calcium into the cytoplasm that provides a condition for absorption of water and cell growth. GA3 is inactivated after growth and calcium returns to the cell wall to stiffen it. After the absorption of water by the seed and following the active absorption stage, the embryo produces GA3 and stimulates aleuronic cells to produce hydrolytic enzymes such as $\alpha$ - and $\beta$ amylase that hydrolyze starch to glucose, which can be absorbed by the embryo. GA3 affects the proteins that produce mRNA and thereby increases DNA replication and induces analysis of endospermic materials in the seed Lahuti et al., (2003).

Table (1) Effect of GA3 on Seed Germination and Seedling Growth of Loquat

\begin{tabular}{|l|l|l|l|l|l|l|l|l|l|l|}
\hline \multirow{2}{*}{\begin{tabular}{l} 
Con. of $\begin{array}{l}\text { GA3 } \\
\left(\mathrm{mg} . \mathrm{L}^{-1}\right)\end{array}$ \\
\cline { 2 - 12 }
\end{tabular}} & $\begin{array}{l}1^{\text {st }} \\
\text { Week }\end{array}$ & $\begin{array}{l}2^{\text {nd }} \\
\text { Week }\end{array}$ & $\begin{array}{c}3^{\text {rd }} \\
\text { Week }\end{array}$ & Shoot & Root & $\begin{array}{l}\text { Vigor } \\
\text { index }\end{array}$ & $\begin{array}{l}\text { Seedling } \\
\text { diameter } \\
(\mathrm{mm})\end{array}$ & $\begin{array}{l}\text { No. } \\
\text { of } \\
\text { leaf }\end{array}$ & $\begin{array}{l}\text { Vegetative dry } \\
\text { weight } \\
(\mathrm{g})\end{array}$ & $\begin{array}{l}\text { Root } \\
\text { dry } \\
\text { weight } \\
(\mathrm{g})\end{array}$ \\
\hline 0 & $54.61 \mathrm{~d}$ & $72.95 \mathrm{~d}$ & $92.65 \mathrm{~d}$ & $4.86 \mathrm{~d}$ & $6.69 \mathrm{~d}$ & $1070.373 \mathrm{~d}$ & $1.51 \mathrm{c}$ & $7.18 \mathrm{~d}$ & $0.09 \mathrm{~d}$ & $0.023 \mathrm{c}$ \\
\hline 200 & $63.26 \mathrm{~b}$ & $77.00 \mathrm{~b}$ & $94.56 \mathrm{~b}$ & $6.80 \mathrm{c}$ & $8.29 \mathrm{~b}$ & $1428.496 \mathrm{c}$ & $1.59 \mathrm{~b}$ & $8.07 \mathrm{~b}$ & $0.18 \mathrm{c}$ & $0.040 \mathrm{ab}$ \\
\hline 250 & $71.19 \mathrm{a}$ & $86.80 \mathrm{a}$ & $98.75 \mathrm{a}$ & $7.36 \mathrm{~b}$ & $8.11 \mathrm{c}$ & $1528.122 \mathrm{~b}$ & $1.69 \mathrm{a}$ & $8.34 \mathrm{a}$ & $0.23 \mathrm{a}$ & $0.044 \mathrm{a}$ \\
\hline 300 & $60.61 \mathrm{c}$ & $\begin{array}{l}76.57 \\
\mathrm{c}\end{array}$ & $\begin{array}{l}94.00 \\
\mathrm{c}\end{array}$ & $8.21 \mathrm{a}$ & $10.15 \mathrm{a}$ & $1726.425 \mathrm{a}$ & $1.58 \mathrm{~b}$ & $7.92 \mathrm{c}$ & $0.22 \mathrm{~b}$ & $0.038 \mathrm{~b}$ \\
\hline
\end{tabular}

A same letter in the column indicates that there is no significant difference $(p<0.05)$.

\section{2- Effect of Soaking period on Seed Germination and Seedling Growth of Loquat}

Table (2) showed that soaking period did not affect significantly on loquat seed germination ratio at $1^{\text {st }}$ and $3^{\text {rd }}$ weeks while in $2^{\text {nd }}$ Week after germination the ratio increased significantly with increasing soaking period, the lowest germination obtained from 20 hours soaked treatments $(76.87 \%)$ and the highest germination $(80.05 \%)$ was obtained from 30 hours soaked seeds. The present results are in agreement with the findings of Dzayi(2010). The higher germination in long time soaked seeds are due to maximum removal of germination inhibitor and proper water uptake which is essential for seed germination. Soaking period affect significantly on seedling growth parameters the highest value was noted in 25 hours soaking $(6.87 \mathrm{~cm})$ shoot length, $(8.59 \mathrm{~cm})$ root length, (1468.201) vigor index, seedling diameter, (7.92) number of leaf and $(0.19,0.043)$ gm. Vegetative and root dry weight. 
Table (2) Effect of Soaking period on Seed Germination and Seedling Growth of Loquat

\begin{tabular}{|c|c|c|c|c|c|c|c|c|c|c|}
\hline \multirow{2}{*}{$\begin{array}{l}\text { Soaking } \\
\text { period } \\
\text { (hrs.) }\end{array}$} & \multicolumn{3}{|c|}{ Seed germination \% } & \multicolumn{2}{|c|}{ Length (cm) } & \multirow{2}{*}{$\begin{array}{l}\text { Vigor } \\
\text { index }\end{array}$} & \multirow{2}{*}{$\begin{array}{l}\text { Seedling } \\
\text { diameter } \\
(\mathrm{mm})\end{array}$} & \multirow{2}{*}{$\begin{array}{l}\text { No. } \\
\text { of } \\
\text { Leaf }\end{array}$} & \multirow{2}{*}{$\begin{array}{l}\text { Vegetative } \\
\text { dry weight } \\
\text { (g) }\end{array}$} & \multirow{2}{*}{$\begin{array}{l}\text { Root dry } \\
\text { weight } \\
\text { (g) }\end{array}$} \\
\hline & $\begin{array}{l}1^{\text {st }} \\
\text { Week }\end{array}$ & $\begin{array}{l}2^{\text {nd }} \\
\text { Week }\end{array}$ & $\begin{array}{l}3^{\text {rd }} \\
\text { Week }\end{array}$ & Shoot & Root & & & & & \\
\hline 20 & $62.39 \mathrm{a}$ & $\begin{array}{l}76.8 \\
7 \mathrm{c}\end{array}$ & $94.88 \mathrm{a}$ & $6.70 \mathrm{~b}$ & $\begin{array}{l}7.82 \\
\mathrm{c}\end{array}$ & $\begin{array}{l}1379.2 \\
39 \mathrm{~b}\end{array}$ & $1.57 \mathrm{~b}$ & $\begin{array}{l}7.82 \\
b\end{array}$ & $0.17 \mathrm{~b}$ & $0.030 \mathrm{c}$ \\
\hline 25 & $62.31 \mathrm{a}$ & $\begin{array}{l}78.0 \\
7 \mathrm{~b}\end{array}$ & $95.18 \mathrm{a}$ & $6.87 \mathrm{a}$ & $\begin{array}{l}8.59 \\
\mathrm{a}\end{array}$ & $\begin{array}{l}1468.2 \\
01 \mathrm{a}\end{array}$ & $1.61 \mathrm{a}$ & $\begin{array}{l}7.92 \\
\mathrm{a}\end{array}$ & $0.19 \mathrm{a}$ & $0.043 \mathrm{a}$ \\
\hline 30 & $62.56 \mathrm{a}$ & $\begin{array}{l}80.0 \\
5 \mathrm{a}\end{array}$ & $94.91 \mathrm{a}$ & $6.860 \mathrm{a}$ & $\begin{array}{l}8.52 \\
\mathrm{~b} \\
\end{array}$ & $\begin{array}{l}1467.6 \\
23 \mathrm{a}\end{array}$ & $1.60 \mathrm{a}$ & $\begin{array}{l}7.90 \\
\mathrm{a}\end{array}$ & $0.186 \mathrm{a}$ & $0.038 \mathrm{~b}$ \\
\hline
\end{tabular}

A same letter in the column indicates that there is no significant difference $(\mathrm{p}<0.05)$.

\section{3- $\quad$ Effect of interaction between GA3 and Soaking Period on Seed Germination and Seedling Growth of Loquat}

Different effects of combined GA3 concentration and soaking period on the seed germination rate and seedling growth parameters (Table3). More significant effect interactions were obtained in $250 \mathrm{mg} . \mathrm{L}^{-1} \mathrm{GA} 3$ with different period times, values germination percentage $(72.41,88) \%$ in $250 \mathrm{mg} . \mathrm{L}^{-1}$ GA3with 30 hours soaking in the $1^{\text {st }}$ and $2^{\text {nd }}$ week and $(99.37 \%)$ in $250 \mathrm{mg}$.L-1 GA3with 25 hours soaking in the $3^{\text {rd }}$ week after seed germination. The lowest germination was found in control and soaking period for 20 hours $52.7 \%$ in $1^{\text {st }}$ week, $70.33 \%$ in $2^{\text {nd }}$ week while control and soaking for 30 hours $91.96 \%$ in the $3^{\text {rd }}$ week. Highest shoot growth was observed in $300 \mathrm{mg} . \mathrm{L}^{-1} \mathrm{GA} 3$ and 20 hours soaking period $8.29 \mathrm{~cm}$, seedling showed more root growth, Vigor index, Seedling diameter, number of leaf and root dry weight in $250 \mathrm{mg} . \mathrm{L}^{-1} \mathrm{GA} 3$ and 30 hours soaking period $(10.52 \mathrm{~cm}, 1792.48,1.77 \mathrm{~mm}, 8.55$ and0.060gm, combination between $250 \mathrm{mg}$.L-1 GA3 and 25 hours soaking period gave highest vegetative dry weight $0.26 \mathrm{gm}$. There was significantly different from control and other treatments (Table 3).

Table (3) Effect of interaction between GA3 and Soaking Period on Seed Germination and Seedling Growth of Loquat

\begin{tabular}{|c|c|c|c|c|c|c|c|c|c|c|c|}
\hline \multirow[b]{2}{*}{$\begin{array}{c}\text { Con. of GA3 } \\
\left(\mathrm{mg} \cdot \mathrm{L}^{-1}\right)\end{array}$} & \multirow{2}{*}{$\begin{array}{c}\text { Soaking } \\
\text { period } \\
\text { (hrs.) }\end{array}$} & \multicolumn{3}{|c|}{ Seed germination \% } & \multicolumn{2}{|c|}{ Length (cm) } & \multirow[b]{2}{*}{ Vigor index } & \multirow{2}{*}{$\begin{array}{c}\text { Seedling } \\
\text { diameter } \\
(\mathrm{mm})\end{array}$} & \multirow[b]{2}{*}{$\begin{array}{l}\text { No. of } \\
\text { leaf }\end{array}$} & \multirow{2}{*}{$\begin{array}{l}\text { Vegetati } \\
\text { ve dry } \\
\text { weight } \\
\text { (g) }\end{array}$} & \multirow{2}{*}{$\begin{array}{c}\text { Root dry } \\
\text { weight } \\
\text { (g) }\end{array}$} \\
\hline & & $\begin{array}{c}1^{\text {st }} \\
\text { Week }\end{array}$ & $\begin{array}{c}2^{\text {nd }} \\
\text { Week }\end{array}$ & $\begin{array}{c}3^{\text {rd }} \\
\text { Week }\end{array}$ & Shoot & Root & & & & & \\
\hline \multirow[t]{3}{*}{0} & 20 & $55.07 \mathrm{~g}$ & $70.33 \mathrm{~h}$ & $93.33 \mathrm{ef}$ & $4.59 \mathrm{j}$ & $6.51 \mathrm{~h}$ & $1036.00 \mathrm{j}$ & $1.51 \mathrm{~g}$ & $7.00 \mathrm{f}$ & $0.12 \mathrm{f}$ & $0.030 \mathrm{e}$ \\
\hline & 25 & $56.04 \mathrm{~g}$ & $73.17 \mathrm{~g}$ & $92.67 \mathrm{fg}$ & $4.80 \mathrm{i}$ & $7.57 \mathrm{e}$ & $1146.29 \mathrm{i}$ & $1.48 \mathrm{~h}$ & $7.21 \mathrm{e}$ & $0.08 \mathrm{~h}$ & $0.030 \mathrm{e}$ \\
\hline & 30 & $52.73 \mathrm{~h}$ & $75.35 \mathrm{f}$ & $91.96 \mathrm{~g}$ & $5.21 \mathrm{~h}$ & $5.98 \mathrm{i}$ & $1028.825 \mathrm{j}$ & $1.54 \mathrm{f}$ & $7.32 \mathrm{e}$ & $0.09 \mathrm{~g}$ & $0.020 \mathrm{f}$ \\
\hline \multirow[t]{3}{*}{200} & 20 & $63.33 \mathrm{C}$ & $75.36 \mathrm{f}$ & $93.67 \mathrm{de}$ & $6.54 \mathrm{~g}$ & $7.57 \mathrm{e}$ & $1314.418 \mathrm{~h}$ & $1.55 \mathrm{f}$ & $8.11 \mathrm{~b}$ & $0.137 \mathrm{e}$ & $0.030 \mathrm{e}$ \\
\hline & 25 & $62.70 \mathrm{~cd}$ & $77.35 \mathrm{~d}$ & $94.33 \mathrm{~d}$ & $7.15 \mathrm{e}$ & $6.69 \mathrm{~g}$ & $1649.327 \mathrm{e}$ & $1.59 \mathrm{e}$ & $7.97 \mathrm{c}$ & $0.19 \mathrm{~d}$ & $0.030 \mathrm{e}$ \\
\hline & 30 & $63.74 \mathrm{c}$ & $78.37 \mathrm{c}$ & $95.67 \mathrm{c}$ & $6.72 \mathrm{f}$ & $6.79 \mathrm{f}$ & $1366.724 \mathrm{~g}$ & $1.61 \mathrm{~d}$ & $8.13 \mathrm{~b}$ & $0.21 \mathrm{c}$ & $0.020 \mathrm{f}$ \\
\hline \multirow[t]{3}{*}{250} & 20 & $71.40 \mathrm{a}$ & $85.37 \mathrm{~b}$ & $97.23 \mathrm{~b}$ & $7.370 \mathrm{c}$ & $9.98 \mathrm{c}$ & $1732.966 \mathrm{~b}$ & $1.55 \mathrm{f}$ & $8.33 \mathrm{a}$ & $0.26 \mathrm{a}$ & $0.023 \mathrm{ef}$ \\
\hline & 25 & $69.75 \mathrm{~b}$ & $86.44 a$ & $99.37 \mathbf{a}$ & $7.46 \mathrm{c}$ & $9.73 \mathrm{~d}$ & $1484.677 \mathrm{f}$ & $1.59 \mathrm{de}$ & $8.13 \mathrm{~b}$ & $0.177 \mathrm{~d}$ & $0.05 \mathrm{ab}$ \\
\hline & 30 & $72.41 \mathrm{a}$ & $88 a$ & $99.7 \mathrm{~b}$ & $7.24 \mathrm{de}$ & $10.52 \mathrm{a}$ & $1792.48 \mathrm{a}$ & $1.77 \mathrm{a}$ & $8.55 \mathrm{a}$ & $0.21 \mathrm{~d}$ & $0.060 \mathrm{a}$ \\
\hline \multirow[t]{3}{*}{300} & 20 & $59.74 \mathrm{f}$ & $76.40 \mathrm{e}$ & $95.29 \mathrm{c}$ & $8.29 \mathrm{a}$ & $9.73 \mathrm{~d}$ & $1679.13 \mathrm{~d}$ & $1.67 \mathrm{~b}$ & $8.13 \mathrm{~b}$ & $0.23 \mathrm{~b}$ & $0.023 \mathrm{ef}$ \\
\hline & 25 & $60.74 \mathrm{ef}$ & $75.30 \mathrm{f}$ & $94.37 \mathrm{~d}$ & $8.07 \mathrm{~b}$ & $10.21 \mathrm{~b}$ & $1707.66 \mathrm{c}$ & $1.62 \mathrm{~d}$ & $7.95 \mathrm{c}$ & $0.22 \mathrm{bc}$ & $0.043 \mathrm{~cd}$ \\
\hline & 30 & $61.34 \mathrm{de}$ & $78.02 \mathrm{c}$ & $92.35 \mathrm{~g}$ & $8.28 \mathrm{a}$ & $7.57 \mathrm{e}$ & $1321.74 \mathrm{~h}$ & $1.64 \mathrm{c}$ & $7.68 \mathrm{~d}$ & $0.23 \mathrm{bc}$ & $0.050 \mathrm{bc}$ \\
\hline
\end{tabular}

\section{References}

[1]. Abdul-baki, A. and J.D. Anderson. 1973. Vigor determination in Soybean seed by multiple criteria. Crop Sci. 13: 630-633.

[2]. Duke, J. A., and E. S. Ayensu. 1985. Medicinal plants of China. Algonac, MI: Reference Publications.

[3]. WEIKAT IM, and LYRENE PM. 1988. Response of high bush blueberry seed germination to gibberellin A3 and 6Nbenzyladenine. Canadian Journal of Botany 67: 3391-3393.

[4]. Dzayi, F. H. Rahman. 2010. Effect of GA3 and Soaking time on Seed Germination and Seedling Growth Lemon (Citrus limon L.) High Diploma.Thesis coll.Agric, univ. of Salahaddin - Erbil.

[5]. El-Dengawy, E. F. A. 1997. Physiological and biochemical studies on seeds dormancy and germination process in deciduous fruit trees. Ph.D. Thesis. Faculty of Agriculture, Mansoura University, Mansoura, Egypt.

[6]. El-Dengawy, E. F. A. 2005. Promotion of seed germination and subsequent seedling growth of loquat (Eriobotrya japonica, Lindl) by moist-chilling and GA3 applications. Sciatia Horticulturae 105: 331-342.

[7]. El-Khoreiby, A. M. K., and T. A. Salem. 1985. Effect of stratification and GA3 on seed germination and subsequent seedling rowth of apricot and peach. Bulletin of Faculty of Agriculture, Cairo University, Egypt 36: 299-309.

[8]. Hartmann, H. T., D. E. Kester, and F. T. Davies Jr. 1990. Plant Propagation Principles and Practices. Englewood Cliffs, NJ: Prentice- Hall.

[9]. International Seed Testing Association, International Rules for Seed Testing, Rules 1996.

[10]. Karam,Ns, and AL-Salem Mm 2001. Breaking dormancy in Arbutus and rachna L. seeds by stratification and gibberellic acid. Seed Science and Technology29:51-56. 
[11]. Mehanna, Ht, Martin Gc, and NISHIJIMA C. 1985. Effects of temperature, chemical treatments and endogenous hormone content on peach seed germination and subsequent seedling growth. Scientia Horticulturae 27: 63-73.

[12]. Nagao, M. A., and S. C. Furutani. 1986. Improving germination of papaya seed by density separation, potassium nitrate and gibberellic acid. HortScience 21: 1439-1440.

[13]. Perry, L. M. 1980. Medicinal Plants of East and Southeast Asia. Cambridge, MA: MIT Press.

[14]. Polat, A. A., 1997. Determination of germination rate coefficients of loquat seeds and their embryos stratified in various media for different durations. Turkish Journal of Agriculture and Forestry 21: 219-224.

[15]. Polat, A. A., and N. Kaska. 1992. Effect of stratification on the germination of loquat (Eriobotrya japonica, Lindl) seeds embryos. Doga, Turk Tarim ve Ormancilik Dergisi 16: 450-459.

[16]. Taha, F. A. 1987. Effect of plant growth regulators on seed germination and seedling characters of persimmon root-sto (Diospyrus kaki L.). Egyptian Journal of Horticulture 14: 15-20.

[17]. Westwood Mn.. 1995. Temperate-zone pomology: physiology and culture. 3rd. Timber Press, Portland, Oregon. 